\title{
PREDICTORS OF MORTALITY IN ACUTELY INTOXICATED PATIENTS ADMITTED TO INTENSIVE CARE UNIT IN MENOUFIA UNIVERSITY HOSPITAL
}

\author{
Shireen Ragab Slima
}

Forensic Medicine and Clinical Toxicology department, Faculty of Medicine, Menoufia University, Egypt

E. mail: Sheren_Ragab@yahoo.com

Mobile phone: 01004144831

Date of submission: 17 May 2020

Revised at: 4 August 2020

Accepted at: 4 August 2020

\section{ABSTRACT}

Background: Acute poisoning is a major cause of suicide and public health problem all over the world. Evaluation of the morbidity and outcome of admitted patients can assess the efficacy of treatment, making it possible to take better decisions and to further improve quality of care. Objectives: The present study was aimed to study multiple factors associated with fatal poisoning of the patients admitted to ICU and to assess APACHE II Scoring System in prediction of poisoning outcome. Material and Methods: in this prospective study, from January 2019 to December 2019, critical patients with acute poisoning admitted to ICU, Menoufia University hospitals-Egypt were enrolled into this study. Data including demographic features, clinical and lab findings, Acute Physiology and Chronic Health Evaluation (APACHE II) at admission, mode and route of poisoning, the need for mechanical ventilation or vasoactive agents, duration of mechanical ventilation and ICU stay were documented, collected and analyzed by the relevant statistical methods. All patients were studied till death or discharge from the ICU. Results: During the study period, 152 out of 1745 patients admitted to the Menoufia poisoning control center (MPCC) were admitted to the ICU. Out of them, 54 died and 98 survived. The majority were in age group (20-40) years. Females were $(62.5 \%)$ of the total cases. Intentional poisoning was predominant. Pesticides were the most commonly employed poison including aluminium phosphide and organophosphorus compounds. Aluminium phosphide was highly toxic. High APACHE II score, mechanical ventilation and inotropic support were associated with high mortality. Conclusion: Some findings were correlated with outcome in acute poisoning and can be used as guidance for risk assessment and treatment planning of the patients. The higher the APACHE II score, the more serious the condition becomes. Proper counseling to counteract the stressful situations to reduce fatalities. In addition, some policy should be applied to control the easy availability of poisons in the society.

Keywords: Acute poisoning, intensive care unit, Mortality

\section{INTRODUCTION}

Poisoning is the major cause of suicide and constitutes a public health problem with various patterns of acute toxicity in different regions of the world. It is an important medical emergency and carries a high morbidity and mortality rate especially in developing countries, resulting in hospitalization and consumption of health care resources (Khodabandeh et al., 2012 and Jha \& Yadav, 2014). Agricultural 
pesticides and envenomation are common causes of poisoning in developing countries while the drug's misuse is commonly seen in industrial and developed countries (Murali et al., 2009 \& Rajbanshi, et al., 2018).

Intensive Care Unit (ICU) represents the highest level of continuing patient care and treatment by highly trained and qualified staff (Ashwini et al., 2016). Poisoned patient with severe intoxication admitted at an ICU due to the potentially unpredictable clinical course. Acutely intoxicated patients associated with profound alteration in any vital sign, hemodynamic instability, altered mental status, severe metabolic acidosis or electrolyte disturbances likely require ICU admission (Kirk, 2011). Early diagnosis and rapid treatment are critical for better outcome (Oreby et al., 2016).

Different scoring systems have been developed for prediction the outcome of critically ill patients. APACHE II is frequently used because it is reliable, inexpensive and easily measurable. The APACHE II score is depending on acute physiological parameters and other clinical information. It calculates the probability of mortality independent of diagnosis. It is less disease specific than other severity measurements (Chhangani et al., 2015).

\section{MATERIAL AND METHODS}

This is a prospective clinical study that was carried out on patients admitted to ICU, Menoufia University Hospitals, during the period from $1^{\text {st }}$ January 2019 to $31^{\text {th }}$ December 2019 after taking informed consent by the studied cases or guardians after explanation of the aim of the study. All collected personal information was treated confidentially. The study plan was approved by Institutional ethical committee following the permission of the authority of the Menoufia poisoning control center.

\section{Study design and grouping}

All acutely poisoned patients of both sexes, ICU-Menoufia University Hospitals over one year, 2019 were included in the current study. Clinical sheet was designed to be fulfilled for every patient including demographic (gender, age, residence and marital status), toxicological and investigational data. According to age, the patients were grouped into three groups: First: less than 20 years; Second: from 20 to 40 years and Third: more than 40 years. APACHE II score was calculated for each patient (appendix). The need for mechanical ventilation or vasoactive agents, duration of mechanical ventilation and ICU stay were documented. Patients were classified according to the outcome into 2 groups survivors and non-survivors.

Diagnosis of agent of poisoning was based on the history of ingestion or exposure taken from the patient or the patient's family (or attendants), characteristic clinical features and the toxicological laboratory examination of biological samples.

APACHE II score ranges from 0 to 71 points. To calculate the APACHE II score, the sum of 12 common physiological and laboratory values was added to a mark adjusting for patient age and a mark adjusting for chronic health problems (severe organ insufficiency or immunocompromised patients) (Knaus et al., 1985).

\section{Statistical analysis}

The statistical analysis of data was performed by using personal computer and SPSS programs statistical package for social science version 23 (SPSS Inc. Released 
2015. IBM SPSS statistics for windows, version 23.0, Armnok, NY: IBM Corp.).

The description of the data was done in the form of Number (No), percentage (\%) mean $(\overline{\mathbf{x}})$ and standard deviation (SD). Student's t-test was used for comparison of nominal variables between two groups of normally distributed data, while Mann Whitney's test was used for comparison of quantitative variables between two groups of not normally distributed data.

- Chi-square test $\left(\chi^{2}\right)$ and Fischer's Exact test were used for categorical variables.

- Receiver operator characteristic (ROC) with respective points of maximal accuracy for sensitivity and specificity were generated to determine biomarker performance.

- Univariate Logistic regression analysis was done to ascertain the effect of certain variable as a predictor for mortality.

- P value of $<0.05$ was considered statistically significant.

\section{RESULTS}

Through the study period, a total of 152 patients (out of 1745 patients admitted to the Menoufia poisoning control center) admitted to ICU representing $8.7 \%$. Out of ICU- admitted patients, 54 died. The mortality rate was $35.5 \%$. Table (1) demonstrates that 57 male $(37.5 \%)$ and 95 female $(62.5 \%)$ patients included in the study. The results show a peak incidence $(57.1 \%$ in survivors and $51.9 \%$ in nonsurvivors) in age group (20-40) years, followed by age group $>40$ years $(23.5 \%$ and $31.5 \%$ for the survivors and the non survivors respectively). The least was among age group $(<20)$ years.
Large proportion $(58.6 \%)$ of all studied cases came from rural areas; the remaining $41.4 \%$ were from urban areas. The largest percentage of cases was single (53.1\% in survivors and $59.3 \%$ in nonsurvivors), while $30.6 \%$ of survivors and $25.9 \%$ of non survivors were married. The remaining cases were widow and divorced. The relation regarding sex, age, resident and marital status was not statistically significant between the two groups.

The results illustrated that $52 \%$ of cases who survived and $88.9 \%$ of dead cases were suicidal, while the remaining percent were accidental. The difference between the two groups was significant $(\mathrm{P}<0.001)$. There were no homicidal cases in the period of study. The most common route was oral ingestion $71.4 \%$ of survivors and $90.7 \%$ of non survivors, followed by dermal exposure and inhalation with significant difference between the survivors and non survivors $(\mathrm{P}<0.05)$.

The time passed since poison administration to hospital arrival was $<6$ hours in $77.6 \%$ of survivors and $38.9 \%$ of non survivors. This difference was statistically significant $(\mathrm{P}<0.001)$. The system used for severity grading was the APACHE II. The mean values were found to be higher for non-survivors $(18.87 \pm 8.03)$ than survivors $(9.74 \pm 7.35)$ with significant difference between the two groups $(\mathrm{P}<0.001)$.

Mechanical ventilation was required in $23.5 \%$ of survivors and in $87 \%$ of nonsurvivors. The mean duration of mechanical ventilation was $0.53 \pm 1.17$ days in survivors and $5.79 \pm 3.96$ days in non-survivors. The duration of ICU stay in $64.3 \%$ of survivors was less than 2 days while $51.9 \%$ of nonsurvivors stayed more than 7 days. The difference was statistically significant $(\mathrm{P}<0.001)$ regarding the use of inotropes, 
mechanical ventilation, duration of mechanical ventilation and ICU stay (Table 2).

Average arterial blood gas values were demonstrated in table (3) as follows: $\mathrm{pH}$ mean values were found to be more acidotic in non-survivors $(7.19 \pm 0.16)$ than survivors $(7.30 \pm 0.12)$. Higher mean values of $\mathrm{PaO}_{2}$ were observed in survivors $(82.90 \pm 9.79)$ compared to non survivors $(72.27 \pm 8.30)$. While, the mean values of $\mathrm{PCO}_{2}$ for survivor cases $(42.99 \pm 11.64)$ were higher than nonsurvivor cases $(54.63 \pm 13.51)$. The mean values of serum bicarbonate were $18.98 \pm$ $2.07 \mathrm{mEq} / \mathrm{L}$ for the survivors and $17.38 \pm$ $1.21 \mathrm{mEq} / \mathrm{L}$ for the non survivors. There was a significant difference between the two groups regarding $\mathrm{pH}, \mathrm{PaO}_{2} \mathrm{PCO}_{2}$ and serum bicarbonate.

Table (3) also shows that both groups of patients had normal mean serum levels of sodium $(137.32 \pm 5.18 \mathrm{mEq} / \mathrm{L}$ for the survivors and $138.22 \pm 3.01 \mathrm{mEq} / \mathrm{L}$ for the non survivors). Regarding serum potassium level, the mean was recorded $3.79 \pm 0.80$ $\mathrm{mEq} / \mathrm{L}$ for the survivors with lower values for the non survivors $(3.44 \pm 0.52 \mathrm{mEq} / \mathrm{L})$. High (AST) levels were detected in survivors $(82.95 \pm 131.41 \mathrm{u} / \mathrm{L})$ and in nonsurvivors $(92.29 \pm 108.53 \mathrm{u} / \mathrm{L})$. Increased serum levels of (ALT) were detected in both survived $(50.69 \pm 52.92 \mathrm{u} / \mathrm{L})$ and nonsurvived cases $(53.22 \pm 46.01 \mathrm{u} / \mathrm{L})$. The mean serum level of creatinine was higher in non survivors $(1.38 \pm 0.52 \mathrm{mg} / \mathrm{dl})$ than survivors $(1.15 \pm 0.53 \mathrm{mg} / \mathrm{dl})$. The difference between the two groups regarding serum potassium, AST and creatinine levels was statistically significant.

Table (4) demonstrates that phosphides, followed by OP and snake bites were the main causes of poisoning. Maximum number of deaths was due to phosphides (63\%), followed by OP insecticides $(16.7 \%)$. Four patients were caused by drug overdose (three were digitalis overdose and one due to sedativehypnotic). Relationship between agents of poisoning with patient outcome revealed statistically significant difference regarding phosphides $(\mathrm{P}<0.001)$.

Table (5) illustrates classification of patients according to their APACHE II score. More survivors were in the lower ranges of APACHE II score as $32.7 \%$ of survived cases had score range (0-5) and $26.5 \%$ of them had score range (6-10) followed by $16.3 \%$ of them in the score range (11-15). The major percent of non survivors was found in higher scores of APACHE II as $24.1 \%$ of mortality cases had score range (16-20) and $22.2 \%$ of them had score range (21-25) followed by $18.5 \%$ of them in the score range (26-30). Patients with APACHE II score $>30$ died. The difference between survivors and non survivors was statistically significant in the ranges (0-5), (6-10), (21-25), (26-30) and $(>30)$ of APACHE II score.

Based on the Receiver operating characteristics (ROC) curve for prediction of mortality using APACHE II score: at a cutoff value of or greater than 12.50, sensitivity is $75.9 \%$, specificity $72.4 \%$, positive predictive value (PPV) 60\%, a negative predictive value (NPV) of $85 \%$, and accuracy $74 \%$ fig. (1).

Logistic regression analysis of the predictors of mortality showed that use of inotropes was the most predicting factor for mortality in the studied cases $(\mathrm{OR}=27.667$; CI: 11.220-68.222, P <0.001) followed by the need for mechanical ventilation (OR=21.894; CI: 8.714-55.010, P <0.001). Delay time $\geq 6$ hours, APACHE II, increased $\mathrm{PCO}_{2}$, hypoxia and acidosis were significant predictors of death $(\mathrm{P}<0.001)$ as shown in (Table 6). 
Table 1: Analysis of Demographic data for survivors and non-survivors admitted to ICU for poisoning.

\begin{tabular}{|c|c|c|c|c|c|c|c|c|c|}
\hline \multirow{2}{*}{\multicolumn{2}{|c|}{ Variables }} & \multicolumn{2}{|c|}{$\begin{array}{c}\text { Survivors } \\
(\mathrm{n}=98)\end{array}$} & \multicolumn{2}{|c|}{$\begin{array}{c}\text { Non- } \\
\text { Survivors } \\
(\mathbf{n}=\mathbf{5 4})\end{array}$} & \multicolumn{2}{|c|}{$\begin{array}{c}\text { Total } \\
(n=152)\end{array}$} & \multirow{2}{*}{$\begin{array}{c}\text { Test of } \\
\text { significance }\end{array}$} & \multirow[t]{2}{*}{$P$ value } \\
\hline & & No & $\%$ & No & $\%$ & No & $\%$ & & \\
\hline \multirow[t]{2}{*}{ Gender } & Male & 35 & 35.7 & 22 & 40.7 & 57 & 37.5 & \multirow[t]{2}{*}{$\chi^{2}=0.375$} & \multirow[t]{2}{*}{0.540} \\
\hline & Female & 63 & 64.3 & 32 & 59.3 & 95 & 62.5 & & \\
\hline \multirow{3}{*}{$\begin{array}{l}\text { Age } \\
\text { (years) }\end{array}$} & $<20$ & 19 & 19.4 & 9 & 16.7 & 28 & 18.4 & \multirow[t]{3}{*}{$\chi^{2}=1.166$} & \multirow[t]{3}{*}{0.558} \\
\hline & $20-40$ & 56 & 57.1 & 28 & 51.9 & 84 & 55.3 & & \\
\hline & $>40$ & 23 & 23.5 & 17 & 31.5 & 40 & 26.3 & & \\
\hline \multirow[t]{2}{*}{ Residence } & Urban & 41 & 41.8 & 22 & 40.7 & 63 & 41.4 & \multirow[t]{2}{*}{$\chi^{2}=0.896$} & \multirow[t]{2}{*}{0.896} \\
\hline & Rural & 57 & 58.2 & 32 & 59.3 & 89 & 58.6 & & \\
\hline \multirow{4}{*}{$\begin{array}{l}\text { Marital } \\
\text { status }\end{array}$} & Single & 52 & 53.1 & 32 & 59.3 & 84 & 55.3 & \multirow[t]{4}{*}{$\mathbf{F E}=0.828$} & \multirow[t]{4}{*}{0.836} \\
\hline & Married & 30 & 30.6 & 14 & 25.9 & 44 & 28.9 & & \\
\hline & Divorced & 6 & 6.1 & 4 & 7.4 & 10 & 6.6 & & \\
\hline & Widow & 10 & 10.2 & 4 & 7.4 & 14 & 9.2 & & \\
\hline
\end{tabular}

$\chi^{2}=$ chi squared test, $\mathbf{F E}=$ Fisher's Exact test 
Table 2: Clinical information for survivors and non-survivors admitted to ICU for poisoning.

\begin{tabular}{|c|c|c|c|c|c|c|c|c|c|}
\hline \multicolumn{2}{|l|}{ Variables } & \multicolumn{2}{|c|}{$\begin{array}{l}\text { Survivors } \\
(\mathrm{n}=98)\end{array}$} & \multicolumn{2}{|c|}{$\begin{array}{l}\text { Non- } \\
\text { Survivors } \\
(\mathbf{n}=\mathbf{5 4})\end{array}$} & \multicolumn{2}{|c|}{$\begin{array}{c}\text { Total } \\
(n=152)\end{array}$} & \multirow[t]{2}{*}{$\chi^{2}$} & \multirow[t]{2}{*}{$\begin{array}{c}\mathbf{P} \\
\text { value }\end{array}$} \\
\hline & & No & $\%$ & No & $\%$ & No & $\%$ & & \\
\hline \multirow{2}{*}{$\begin{array}{ll}\text { Mode } & \text { of } \\
\text { poisoning }\end{array}$} & Suicidal & 51 & 52.0 & 48 & 88.9 & 99 & 65.1 & \multirow[t]{2}{*}{20.81} & \multirow[t]{2}{*}{$<0.001$} \\
\hline & Accidental & 47 & 48.0 & 6 & 11.1 & 53 & 34.9 & & \\
\hline \multirow{3}{*}{$\begin{array}{l}\text { Route of } \\
\text { poisoning }\end{array}$} & Oral & 70 & 71.4 & 49 & 90.7 & 119 & 78.3 & \multirow{3}{*}{7.640} & \multirow[t]{3}{*}{0.019} \\
\hline & Inhalation & 11 & 11.2 & 2 & 3.7 & 3 & 5.6 & & \\
\hline & Dermal & 17 & 17.3 & 3 & 5.6 & 20 & 13.2 & & \\
\hline \multirow{2}{*}{$\begin{array}{l}\text { Time } \\
\text { (exposure/ } \\
\text { arrival) }\end{array}$} & $<6$ hours & 76 & 77.6 & 21 & 38.9 & 97 & 63.8 & \multirow[b]{2}{*}{22.537} & \multirow[t]{2}{*}{$<0.001$} \\
\hline & $\geq 6$ hours & 22 & 22.4 & 33 & 61.1 & 55 & 36.2 & & \\
\hline \multicolumn{2}{|c|}{$\begin{array}{l}\text { APACHE II (mean } \pm \text { SD) } \\
\text { Median }\end{array}$} & \multicolumn{2}{|c|}{$\begin{array}{l}9.74 \pm 7.35 \\
7.00\end{array}$} & \multicolumn{2}{|c|}{$\begin{array}{l}18.87 \pm 8.03 \\
18.50\end{array}$} & \multicolumn{2}{|c|}{$\begin{array}{l}12.98 \pm 8.75 \\
11\end{array}$} & $\mathrm{U}=\mathbf{6 . 0 7 2}$ & $<0.001$ \\
\hline \multirow{2}{*}{$\begin{array}{l}\text { Inotrope } \\
\text { support }\end{array}$} & yes & 15 & 15.3 & 45 & 83.3 & 60 & 39.5 & \multirow[t]{2}{*}{67.43} & \multirow[t]{2}{*}{$<0.001$} \\
\hline & no & 83 & 84.7 & 9 & 16.7 & 92 & 60.5 & & \\
\hline \multirow{2}{*}{$\begin{array}{l}\text { Mechanical } \\
\text { ventilation }\end{array}$} & yes & 23 & 23.5 & 47 & 87.0 & 70 & 46.1 & \multirow[t]{2}{*}{56.627} & \multirow[t]{2}{*}{$<0.001$} \\
\hline & no & 75 & 76.5 & 7 & 13.0 & 82 & 53.9 & & \\
\hline \multicolumn{2}{|c|}{$\begin{array}{l}\text { Duration of } \text { Mechanical } \\
\text { ventilation (days) } \\
\text { Median }\end{array}$} & \multicolumn{2}{|c|}{$\begin{array}{l}0.53 \pm 1.17 \\
0.00\end{array}$} & \multicolumn{2}{|c|}{$\begin{array}{l}5.79 \pm 3.96 \\
5.00\end{array}$} & \multicolumn{2}{|c|}{$\begin{array}{l}2.40 \pm 3.57 \\
0.00\end{array}$} & $\mathrm{U}=\mathbf{8 . 9 6 6}$ & $<0.001$ \\
\hline \multirow{3}{*}{$\begin{array}{l}\text { Total ICU } \\
\text { Days }\end{array}$} & $<2$ days & 63 & 64.3 & 14 & 25.9 & 77 & 50.7 & \multirow[t]{3}{*}{32.587} & \multirow[t]{3}{*}{$<0.001$} \\
\hline & 2-7 days & 24 & 24.5 & 12 & 22.2 & 36 & 23.7 & & \\
\hline & $>7$ days & 11 & 11.2 & 28 & 51.9 & 39 & 25.7 & & \\
\hline \multirow[t]{2}{*}{ Tracheostomy } & yes & 0 & 0.0 & 2 & 3.7 & 2 & 1.3 & \multirow[t]{2}{*}{$\mathrm{FE}=3.678$} & 0.125 \\
\hline & no & 98 & 100.0 & 52 & 96.3 & 150 & 98.7 & & \\
\hline
\end{tabular}

SD: standard deviation, P significant <0.05 APACHE II: Acute Physiology and Chronic Health Evaluation, ICU: Intensive Care Unit

$\chi^{2}=$ chi squared test, $\mathbf{F E}=$ Fisher's Exact test, $\mathbf{U}=$ Mann Whitney test 
Table 3: Relation between the initial laboratory parameters of patients with their outcome

\begin{tabular}{|c|c|c|c|c|}
\hline & $\begin{array}{c}\text { Survivors } \\
(\mathrm{n}=98) \\
\text { Mean } \pm \text { SD } \\
\text { Median } \\
\end{array}$ & $\begin{array}{c}\text { Non-Survivors } \\
(\mathrm{n}=54) \\
\text { Mean } \pm \text { SD } \\
\text { Median } \\
\end{array}$ & $\begin{array}{c}\text { Test of } \\
\text { significance }\end{array}$ & $P$ value \\
\hline pH & $\begin{array}{l}7.30 \pm 0.12 \\
7.33\end{array}$ & $\begin{array}{l}7.19 \pm 0.16 \\
7.20\end{array}$ & $t=7.724$ & $<0.001$ \\
\hline $\mathrm{PaO}_{2}(\mathrm{mmHg})$ & $\begin{array}{l}82.90 \pm 9.79 \\
86.00\end{array}$ & $\begin{array}{l}72.27 \pm 8.30 \\
72.0\end{array}$ & $t=6.690$ & $<0.001$ \\
\hline $\mathrm{PCO}_{2}(\mathrm{mmHg})$ & $\begin{array}{l}42.99 \pm 11.64 \\
38.00\end{array}$ & $\begin{array}{l}54.63 \pm 13.51 \\
60.0\end{array}$ & $\mathrm{t}=5.332$ & $<0.001$ \\
\hline $\mathrm{HCO}_{3}(\mathrm{mEq} / \mathrm{L})$ & $\begin{array}{l}18.98 \pm 2.07 \\
19.00\end{array}$ & $\begin{array}{l}17.38 \pm 1.21 \\
17.20\end{array}$ & $t=6.006$ & $<0.001$ \\
\hline $\mathrm{Na}^{+}(\mathrm{mEq} / \mathrm{L})$ & $\begin{array}{l}137.32 \pm 5.18 \\
136.0\end{array}$ & $\begin{array}{l}138.22 \pm 3.01 \\
137.00\end{array}$ & $\mathrm{t}=1.346$ & 0.180 \\
\hline $\mathbf{K}^{+}(\mathbf{m E q} / \mathbf{L})$ & $\begin{array}{l}3.79 \pm 0.80 \\
3.50\end{array}$ & $\begin{array}{l}3.44 \pm 0.52 \\
3.30\end{array}$ & $t=3.156$ & 0.002 \\
\hline $\operatorname{AST}(u / L)$ & $\begin{array}{l}82.95 \pm 131.41 \\
35.50\end{array}$ & $\begin{array}{l}92.29 \pm 108.53 \\
65.0\end{array}$ & $\mathrm{U}=\mathbf{2 . 1 0}$ & 0.036 \\
\hline ALT (u/L) & $\begin{array}{l}50.69 \pm 52.92 \\
34.50\end{array}$ & $\begin{array}{l}53.22 \pm 46.01 \\
33.0\end{array}$ & $\mathrm{U}=0.227$ & 0.820 \\
\hline $\begin{array}{l}\text { Creatinine } \\
\text { (mg/dl) }\end{array}$ & $\begin{array}{l}1.15 \pm 0.53 \\
1.10\end{array}$ & $\begin{array}{l}1.38 \pm 0.52 \\
1.30\end{array}$ & $\mathrm{U}=2.628$ & 0.009 \\
\hline
\end{tabular}

SD: Standard deviation, $\mathbf{P}$ significant <0.05 PH: Power of hydrogen $\mathbf{P O}_{2}$ : Partial oxygen pressure $\mathbf{P C O}_{2}$ : Partial carbon dioxide pressure $\mathrm{HCO}_{3}$ : Serum bicarbonate $\mathrm{Na}^{+}$: Serum sodium $\mathbf{K}^{+}$: Serum potassium AST: Aspartate transaminase ALT: Alanine transaminase $\mathbf{t}=$ Students' t-test, $\mathbf{U}=$ Mann Whitney test

Table 4: Agents of poisoning and their relation to patient outcome

\begin{tabular}{|c|c|c|c|c|c|c|c|c|}
\hline & \multicolumn{2}{|c|}{$\begin{array}{c}\text { Survivors } \\
(\mathbf{n}=98)\end{array}$} & \multicolumn{2}{|c|}{$\begin{array}{c}\text { Non- } \\
\text { Survivors } \\
(\mathrm{n}=\mathbf{5 4}) \\
\end{array}$} & \multicolumn{2}{|c|}{$\begin{array}{c}\text { Total } \\
(n=152)\end{array}$} & \multirow[t]{2}{*}{$\mathrm{Z}$ test } & \multirow[t]{2}{*}{$P$ value } \\
\hline & No & $\%$ & No & $\%$ & No & $\%$ & & \\
\hline Phosphides & 18 & 18.4 & 34 & 63.0 & 52 & 34.2 & 5.37 & $<0.001 *$ \\
\hline Organophosphorus & 28 & 28.6 & 9 & 16.7 & 37 & 24.3 & 1.55 & 0.150 \\
\hline Snake bite & 12 & 12.2 & 3 & 5.6 & 15 & 9.9 & 1.02 & 0.306 \\
\hline Carbon monoxide & 11 & 11.2 & 2 & 3.7 & 13 & 8.6 & 0.100 & 0.200 \\
\hline Corrosive & 8 & 8.2 & 1 & 1.9 & 9 & 5.9 & 1.21 & 0.225 \\
\hline Kerosene & 6 & 6.1 & 2 & 3.7 & 8 & 5.3 & 0.26 & 0.798 \\
\hline Methanol & 5 & 5.1 & 2 & 3.7 & 7 & 4.6 & 0.01 & 0.991 \\
\hline Hydrogen Cyanamide & 5 & 5.1 & 1 & 1.9 & 6 & 3.9 & 0.53 & 0.593 \\
\hline Drug overdose & 4 & 4.1 & 0 & 0.0 & 4 & 2.6 & 0.98 & 0.327 \\
\hline Para-phenylenediamine & 1 & 1.0 & 0 & 0.0 & 1 & 0.7 & 0.32 & 0.747 \\
\hline
\end{tabular}

*significant $\mathbf{P}<\mathbf{0 . 0 0 1}$ 
Table 5: Range of APACHE II score among studied patients in relation to the patient outcome

\begin{tabular}{|c|c|c|c|c|c|c|c|c|}
\hline \multirow[t]{2}{*}{ APACHE II Scores } & \multicolumn{2}{|c|}{$\begin{array}{c}\text { Survivors } \\
(\mathrm{n}=98)\end{array}$} & \multicolumn{2}{|c|}{$\begin{array}{c}\text { Non-Survivors } \\
(\mathrm{n}=\mathbf{5 4})\end{array}$} & \multicolumn{2}{|c|}{$\begin{array}{c}\text { Total } \\
(n=152)\end{array}$} & \multirow[t]{2}{*}{$Z$ test } & \multirow[t]{2}{*}{$P$ value } \\
\hline & No & $\%$ & No & $\%$ & No & $\%$ & & \\
\hline $0-5$ & 32 & 32.7 & 2 & 3.7 & 34 & 22.4 & 3.90 & $<0.001 *$ \\
\hline $6-10$ & 26 & 26.5 & 6 & 11.1 & 32 & 21.1 & 2.02 & $0.043 *$ \\
\hline 11-15 & 16 & 16.3 & 7 & 13.0 & 23 & 15.1 & 0.31 & 0.758 \\
\hline 16-20 & 12 & 12.2 & 13 & 24.1 & 25 & 16.4 & 1.67 & 0.095 \\
\hline 21-25 & 8 & 8.2 & 12 & 22.2 & 20 & 13.2 & 2.19 & 0.028* \\
\hline $26-30$ & 4 & 4.1 & 10 & 18.5 & 14 & 9.2 & 2.64 & 0.008* \\
\hline$>\mathbf{3 0}$ & 0 & 0.0 & 4 & 7.4 & 4 & 2.6 & 2.20 & $0.027 *$ \\
\hline
\end{tabular}

* Significant p $<0.05$

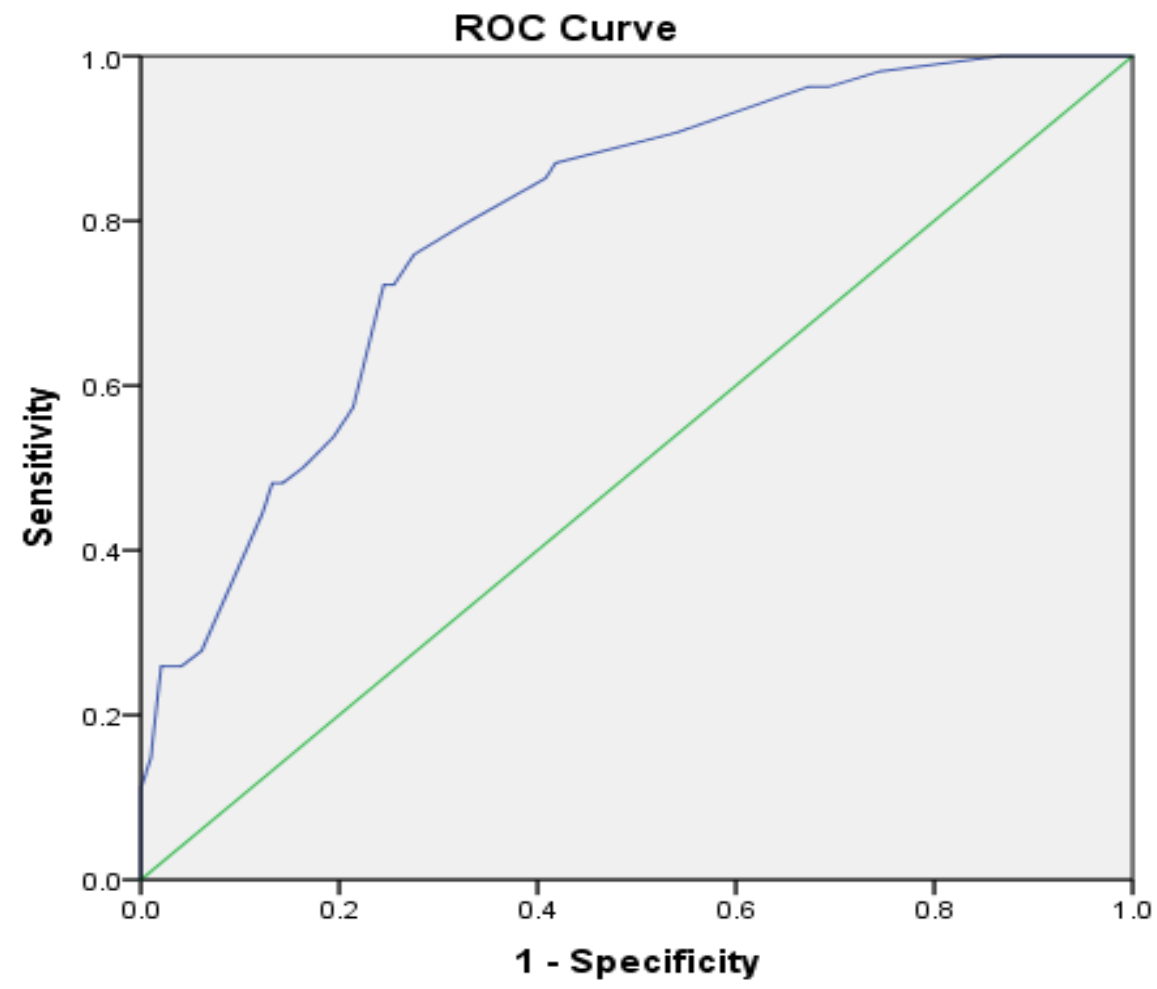

Diagonal segments are produced by ties.

Figure 1: Receiver operating characteristics (ROC) curve for prediction of mortality using APACHE II score: AUC was 0.797 , at point of or greater than 12.50 , sensitivity is $75.9 \%$, specificity $72.4 \%$, PPV $60 \%$, NPV $85 \%$, accuracy $74 \%$. 
Table 6: Logistic regression analysis of the predictors of mortality

\begin{tabular}{|l|l|l|l|l|}
\hline Variable & \multicolumn{1}{|c|}{ P value } & \multirow{2}{*}{ Odds ratio } & \multicolumn{2}{c|}{ 95\% CI } \\
\cline { 4 - 5 } & & & \multicolumn{1}{|c|}{ Lower } & Upper \\
\hline $\begin{array}{l}\text { Delay time } \\
\text { 6 hours }\end{array}$ & $<\mathbf{0 . 0 0 1}$ & 5.429 & 2.631 & 11.20 \\
\hline PCO $_{2}$ & $<\mathbf{0 . 0 0 1}$ & 1.069 & 1.040 & 1.099 \\
\hline PO2 $_{2}$ & $<\mathbf{0 . 0 0 1}$ & 0.896 & 0.862 & 0.933 \\
\hline APACHE II & $<\mathbf{0 . 0 0 1}$ & 1.147 & 1.093 & 1.204 \\
\hline $\begin{array}{l}\text { Mechanical } \\
\text { ventilation }\end{array}$ & $<\mathbf{0 . 0 0 1}$ & 21.894 & 8.714 & 55.010 \\
\hline Inotropes & $<\mathbf{0 . 0 0 1}$ & 27.667 & 11.220 & 68.222 \\
\hline PH & $<\mathbf{0 . 0 0 1}$ & 0.005 & 0.000 & 0.060 \\
\hline
\end{tabular}

CI: confidence interval

\section{DISCUSSION}

Poisoning is on the rise despite of great efforts to combat its occurrence. The general public awareness that poisoning causes almost painless death, leads to rapid rise of death incidence due to poisoning (Harish et al., 2006).

Over one year, 2019, the ICU admitted poisoned cases represented $8.7 \%$ of the total Menoufia poisoning control center (MPCC) admissions. This coincided with the Iranian study of Taghaddosinejad et al., (2012) who revealed that patients requiring ICU admission constituted $8 \%$ of the total cases admitted for treatment of poisoning.

The mortality rate was $35.5 \% \quad(54$ cases out of 152). This was higher than the study of Singh et al., (2018) who recorded a mortality rate of $27 \%$. The high mortality in the current study can be explained by ICU admission was strictly limited to obviously severe and life-threatening poisoning due to the presence of a lower intensity setting "intermediate care" in Menoufia poisoning control center (MPCC).
The current study revealed that most of the cases were in the age group (20-40 years) which is similar with observations of Chaudhary et al., (2013). People in this age group are usually more vulnerable to various emotional conflicts due to their immaturity to cope the stress, their inability to carry new responsibilities, family problems, psychiatric illness, academic failures and poor communication with family (Ahmed et al., 2014).

Females were dominant and this can be explained by the fact that females are easily emotionally and mentally affected by the issues such as household violence and love affair failures (Rajbanshi et al., 2018). Young female used suicidal attempts to oblige her family to do her wishes.

Most cases belonged to the rural area. Menoufia is an agriculture governorate, also farming activity and grain storing is more in rural areas with easy access to toxic pesticides especially organophosphates and phosphides which constituted the most common agent of poisoning in the studied cases. Menoufia University Hospital is a reference hospital for cases of poisoning in Menoufia governorate. Cases of poisoning 
from rural areas are referred to Menoufia poisoning control center (MPCC). This coincided with the Egyptian study of Oreby et al., (2016) that was carried out on patients with acute poisoning admitted to ICU of ElMansoura General Hospital.

Suicidal poisoning represented $65.1 \%$ of the total studied cases (52\% of Survivors and $88.9 \%$ of dead cases) due to easy availability and the thinking that poisoning will be less painful. Similarly, Sulaj et al., (2015) studied toxic cases treated in ICU and recorded that the intentional poisoning constituted $87.2 \%$ of cases with no cases involving homicidal poisoning. Moreover, Boshehri et al., (2012) in their study found that most of died cases were poisoned intentionally. This is in contrast with the study of Coşkun et al., (2013) in Turkey who found that the mortality rate due to accidental poisoning was significantly higher than suicidal poisoning. They explained that lower fatality in their suicidal cases may be due to small amount of ingested poison to draw attention only, vomiting after ingestion and rapid referral to the hospital.

The most common route of poisoning was ingestion $(78.3 \%)$ followed by dermal exposure $(13.2 \%)$ then inhalation $(5.6 \%)$ of the total cases as the highest numbers of admitted cases were intoxicated due to suicidal ingestion of organophosphates and phosphides. This was in agreement with the work of Boshehri et al., (2012).

Acute poisoning is as all medical emergencies, early diagnosis followed by rapid decontamination and definitive treatment are lifesaving. The time passed since poison administration was $\geq 6$ hours in $61.1 \%$ of non-survivors. This was similar with observations of Coşkun et al., (2013).
Longer ICU stay was observed in nonsurvivors because of high poison load and they were mechanically ventilated and some of them developed secondary complications. These patients, though on ventilator, keep worsening and die eventually. This finding is in conformity with those of other workers who recorded lower mortality in short-stay patients (less than two days in the ICU) than in long-stay patients (Ashwini et al., 2016).

Mechanical ventilation and inotropic support were needed in most of dead cases in ICU. These results were in accordance with the study of Mathai and Bhanu (2010) who found that the need for mechanical ventilation and vasoactive drugs is associated with high mortality in aluminum phosphide (ALP) poisoned patients.

This study revealed that hypoxia is associated with high mortality rate. Partial oxygen pressure $\left(\mathrm{PO}_{2}\right)$ was significantly decreased in non survivors. This was previously confirmed by other researchers. Barco et al., (2008) stated that intubation was required in cases of severe OP poisoning with respiratory failure due to muscarinic manifestations or an intermediate syndrome. Moreover, Jayashree and Singhi, (2011) demonstrated that hypoxemia on arrival is associated with higher need for mechanical ventilation and higher incidence of secondary pneumonia with prolonged ICU stay.

The current study demonstrated a significant difference between blood $\mathrm{pH}$ in relation to the outcome. The study of Assaf et al., (2019) was in the same line. Abd Elghany et al., (2018) mentioned that acidosis was related to higher fatality in aluminum phosphide poisoning.

Lower potassium levels were recorded in non survivors. This was previously 
recorded by El-Sarnagawy, (2017). Hypokalemia aggravates muscular weakness and the clinical burden in poisoned patients. The morbidity and mortality related to hypokalemia are secondary to cardiac arrhythmia or respiratory failure (Prasad, 2014).

Increased serum levels of (AST) and (ALT) were detected in both groups with higher (AST) levels especially in nonsurvivors. Similarly, Risal et al., (2019) recorded elevation of serum aminotransferases mainly AST levels in OP poisoning cases. Prasad et al., (2016) demonstrated elevation of (AST) and (ALT) levels in acute zinc phosphide poisoning and found to be significant with mortality. Hepatocyte injury leads to altered cell membrane permeability with excessive leakage of transaminases. Periportal cells have relatively more ALT, while the cells near the central vein which are more likely involved in toxic insults have more AST, causing a predominance of AST elevation (Kasarala and Tillmann, 2016). Aminotransferases especially AST are also elevated due to rhabdomyolysis (Weibrecht et al., 2010).

Higher creatinine levels were recorded in non survivors. Phosphides induced toxic myocarditis causes severe haemodynamic instability leading to hypotension which is accompanied by acute tubular necrosis. Phosphine gas is excreted through respiration and urination, so inadequate renal perfusion and decreased urine output can affect outcome in acute phosphides poisoning (Farzaneh et al., 2018). In another study on organophosphorus poisoning mortality in India by Banday et al., (2015), they observed altered renal function between the survivors and non survivors and stated that the renal injury may be due to direct action of the organophosphate causing tubular necrosis or secondary mechanisms causing hypovolemic shock and rhabdomyolysis.

Mortality was high in patients with acute pesticide poisoning, especially phosphides poisoning. Since rodents usually share human environments, rodenticides represent a great danger to individuals and are among the most lethal compounds routinely found in homes (Nalabothu et al., 2015).

The case fatality rate from phosphides alone was $65.4 \%$ (34/52 cases). Singh et al., (2011) observed $100 \%$ mortality in patients presented with aluminium phosphide poisoning admitted in intensive care unit. It is widely used as a rodenticide and as a grain preservative. Easy availability, low cost and social believes about its painless fatal outcome may direct persons to use its tablets for suicide. Multi-organ involvement and unavailability of any antidote led to maximum deaths due to ALP poisoning (Nejad et al., 2012).

The pattern of poisoning deaths varies in different geographical areas. Krakowiak et al., (2017) in their study in Poland reported that Alcohol poisoning was responsible for maximum number of fatal cases followed by pharmaceutical agents.

A female patient was presented with suicidal ingestion of a black stone which is added to henna. She developed altered liver and kidney functions. Paraphenylenediamine (PPD) is widely used in several industrial products and added to black henna used as temporary tattoo and hair dye to increase its effectiveness. It is an oxidative chemical that can cause hypersensitivity reactions and systemic effects as angioedema, rhabdomyolysis and acute renal failure (Elevli et al., 2014). Another case was 
reported by Şık and Çıtak, (2016) in Turkey after its dermal application.

The present study showed that the initial APACHE II score is a useful prognostic indicator and can predict the outcome of critically poisoned patients. It was useful for stratifying patients according to the severity of their illness. The higher the score was, the higher the mortality rate was. The APACHE II score cut-off point between survivors and non-survivors was determined to be 12.5 with a sensitivity of $75.9 \%$ and specificity $72.4 \%$. Kang et al., (2009) and Coskun et al., (2015) found that the initial APACHE II score was a significant predictor of outcome in acute organophosphate poisoning. Louriz et al., (2009); Mathai and Bhanu (2010) and Abd Elghany et al., (2018) found that APACHE II score was positively correlated with mortality in acute aluminum phosphide poisoning.

This was also recorded by Eizadi Mood et al., (2011) in prediction of outcome of patients with mixed drug poisoning-induced coma. Moreover, ElGharbawy and Khalifa, (2019) studied Egyptian patients of acute carbon monoxide poisoning and found a statistically significant difference between the survived and non-survived cases regarding the values of APACHE II.

\section{CONCLUSION}

Mortality in patients can be predicted by clinical and laboratory parameters. Mortality is directly proportionate to the lag time in initiation of treatment, clinical severity, mechanical ventilation and inotropic therapy. Acidosis and hypoxia were also significant predictors of outcome of acutely intoxicated patients. Rapid diagnosis, early effective treatment and good ICU supportive care will decrease mortality rate in these cases. Aluminium phosphide is the leading cause of deaths observed in Menoufia.

The APACHE II score was discriminator between survivors and nonsurvivors. The results of the current study demonstrate its value for prediction of outcome in critically poisoned patients.

\section{RECOMMENDATIONS}

- Accelerate the transport of poisoned patients to treatment centers.

- Obtaining the maximum information possible from the accompanying persons as well as from the first care givers facilitates rapid diagnosis and early treatment.

- Patients presented with acidosis or hypoxia should be closely monitored and aggressively treated.

- Laws controlling the availability of pesticides can help reduce cases of these preventable causes of death with restricting the sale and storage of aluminium phosphide.

- Less toxic alternatives to aluminium phosphide and organophosphorus compounds should be developed with increasing the awareness of the public to the high fatality of these poisons.

\section{REFERENCES}

\section{Abd Elghany SA, Heshmat MM, Oreby $M$ and Elsarnagawy GN (2018): Evaluation of Various Scoring Systems in Prediction of Acute Aluminum Phosphide (ALP) Poisoning Outcome, Ain Shams J Forensic Med Clin Toxicol, (30): 117- 127.}

\section{Ahmed SM, Das B, Nadeem A and Samal RK (2014): Survival pattern in patients with acute organophosphate}


poisoning on mechanical ventilation: A retrospective intensive care unitbased study in a tertiary care teaching hospital. Indian J Anaesth; 58:11-7.

Ashwini D, Inamdar I.F, Ubaidulla M, Gachhe J, Katare A (2016): Morbidity Pattern and Outcome of Patients Admitted at Intensive Care Centre of a Tertiary Care Hospital, Journal of Dental and Medical Sciences, 15 (10) Ver. XII: 38-43.

\section{Assaf AA, Abd El Kareem MA and Hasb} Elnabi MA (2019): Outcome Prediction in Acutely Intoxicated Patients Admitted to Intensive Care Unit, Ain Shams Journal of Forensic Medicine and Clinical Toxicology, 33: 16-23.

Banday TH, Tathineni B, Desai MS, Naik V (2015): Predictors of morbidity and mortality in organophosphorus poisoning: A case study in rural hospital in Karnataka, India. North Am J Med Sci; 7:259-65.

Barco JC, Omar C, Puiguriguer J, Coll I, Barceló B, Castanyer T (2008): Review of severe organophosphate poisonings over a period of 11 years (1996-2006) Emergencias; 20: 207211.

Boshehri B, Salimi $\mathrm{S}$ and Ranjbar $\mathrm{S}$ (2012): Mortality from Acute Poisoning in Urmia: A Three- Year Retrospective Study. Iran Red CresMed J.; 14(12):838-9.

Chaudhary S, Momin S.G, Vora D.H., Modi P, Chauhan V, Chotaliya D (2013): An Epidemiological Study of Fatal Aluminium Phosphide Poisoning at Rajkot, Journal of Pharmacy, 3(1): 17-23.
Coşkun R, Gündoğan K, Ată̆ E, Akbudak İ H, Öztürk A, Güven M, et al., (2013): Predictors of Mortality in Critically Ill Patients with Poisoning: A Single Center Experience, Turkiye Klinikleri J Med Sci; 33(5):1274-82.

Coskun R, Gundogan K, Sezgin GC, Topaloglu US, Hebbar G, Guven M, et al., (2015): A retrospective review of intensive care management of organophosphate insecticide poisoning: Single center experience. Niger J Clin Pract; 18:644-50.

Eizadi Mood N, Sabzghabaee AM, Khalili Dehkordi Z (2011): Applicability of different scoring systems in outcome prediction of patients with mixed drug poisoning-induced coma. Indian $\mathbf{J}$ Anaesth; 55:599-604.

Elevli M, Civilibal M, Ersoy O, Demirkol D, Gedik AH (2014): Paraphenylenediamine hair dye poisoning: an uncommon cause of rhabdomyolysis. Indian J Pediatr;7: 709-711.

El-Gharbawy DM and Khalifa HK (2019): Assessment of Some Scoring Systems in Prediction of Mortality in Acute Carbon Monoxide Poisoned Patients, Mansoura J. Forens. Med. Clin. Toxicol., 27(1): 87- 102.

El-Sarnagawy GN (2017): Predictive Factors of Mortality in Acute Aluminum Phosphide Poisoning: 5 Years Retrospective Study in Tanta Poison Control Unit, Ain Shams J Forensic Med Clin Toxicol, (29): 7079. 
Farzaneh E, Ghobadi H, Akbarifard M, Nakhaee S, Amirabadizadeh A, Akhavanakbari G, et al., (2018): Prognostic Factors in Acute Aluminium Phosphide Poisoning: A Risk-Prediction Nomogram Approach, Basic \& Clinical Pharmacology \& Toxicology, 123, 347-355.

Harish D, Sharma BR, Chavali KH, Sharma A (2006): Poisoning Mortality in Chandigarh: An Overview, Journal of the Indian Academy of Forensic Medicine, 28 (3):110-113.

Jayashree $M$ and Singhi S (2011): Changing Trends and Predictors of Outcome in Patients with Acute Poisoning Admitted to the Intensive Care, Journal of Tropical Pediatrics, 57(5):340-346.

Jha S and Yadav BN (2014): An analysis of acute fatal poisoning cases coming to mortuary of BPKIHS, Dharan. International Journal of Therapeutic Applications, 17:10-15.

Kang EJ, Seok SJ, Lee KH, Gil HW, Yang JO, Lee EY, et al., (2009): Factors for Determining Survival in Acute Organophosphate Poisoning, Korean J Intern Med;24:362-367.

Kasarala G and Tillmann H L (2016): Standard Liver Tests, Clinical Liver Disease, 8 (1):13-18.

Khodabandeh F, Emamhadi MA and Mostafazadeh B (2012): Epidemiological Assessment of Acute Poisoning Death-One Year Survey. International Journal of Medical Toxicology and Forensic Medicine; 2(3):103-109.
Kirk MA (2011): Use of the intensive care unit. In: Goldfrank's Manual of Toxicologic Emergencies by Flomenbaum NE, Goldfrank LR, Hoffman RS, Howland MA, Lewin NA, Nelson SL (Eds.), $9^{\text {th }}$ edition, The McGraw-Hill, New York: 148-153.

Knaus W.A, Draper E.A, Wagner D.P, et al., (1985): APACHE II: a severity of disease classification system, Crit. Care Med., 13: 818-829.

Krakowiak A, Piekarska-Wijatkowska A, Kobza-Sindlewska K, Rogaczewska A, Politański P, Hydzik P, et al., (2017): Poisoning deaths in Poland: Types and frequencies reported in Łódź, Kraków, Sosnowiec, Gdańsk, Wrocław and Poznań during 20092013. Int J Occup Med Environ Health.; 30(6):897-908.

Louriz, M.; Dendane, T.; Abidi, K.; et al. (2009): "Prognostic factors of acute aluminum phosphide poisoning". Indian J. Med. Sci., 63:227-234.

Mathai, A. and Bhanu, M.S. (2010): "Acute aluminium phosphide poisoning: Can we predict mortality?" Indian J. Anaesth., 54 (4):302-307.

Murali R, Bhalla A, Singh D, Singh $\mathbf{S}$ (2009): Acute pesticide poisoning: 15 years' experience of a large NorthWest Indian hospital Clin Toxicol (Phila).; 47(1): 35-38.

Nalabothu M, Monigari $N$ and Acharya $R$ (2015): Clinical Profile and Outcomes of Rodenticide Poisoning in Tertiary Care Hospital, International Journal of Scientific and Research Publications, 5(8):1-12. 
Nejad FT, Mohammadi AB, Behnoush B, Kazemifar AM, Nahandi MZ, Dabiran S, et al., (2012): Predictors of Poor Prognosis in Aluminum Phosphide Intoxication, Iranian Journal of Toxicology, 6 (16) :610614.

Oreby M, Maklad A, Shihab N and Kassem H (2016): Prediction of Outcome of Acutely Intoxicated Patients Admitted to Intensive Care Unit in Mansoura-Dakhlia Governorate-Egypt, Ain Shams J Forensic Med Clin Toxicol, (26): 140150.

Prasad DRMM (2014): Reduced Levels of Serum Potassium and Plasma Cholinesterase in Acute Organophosphate Poisoning: Possible Predictive Markers. Asia Pac J Med Toxicol; 3:68-72.

Prasad SB, Karunanidhi K, Manohar V, Mohan N, Sreekrishnan TP, Gireeshkumar KP, et al., (2016): Aspartate Aminotransferase Level as a Prognostic Marker in Acute Zinc Phosphide Poisoning, Eurasian J Emerg Med; 15: 39-43.

Rajbanshi LK, Arjyal B and Mandal R (2018): Clinical profile and outcome of patients with acute poisoning admitted in intensive care unit of tertiary care center in Eastern Nepal. Indian J Crit Care Med; 22:691-6.
Risal, P., Lama, S., Thapa, S., Bhatta, R., Karki, R. (2019): Cholinesterase and Liver Enzymes in Patients with Organophosphate Poisoning. Journal of Nobel Medical College, 8(1): 33-37.

Şık G and Çıtak A (2016): Fatal paraphenylenediamine poisoning due to black henna. Turk J Pediatr; 58: 301-304.

Singh O, Javeri Y, Juneja D, Gupta M, Singh G, Dang R (2011): Profile and outcome of patients with acute toxicity admitted in intensive care unit: Experiences from a major corporate hospital in urban India. Indian $\mathbf{J}$ Anaesth; 55:370-4.

Sulaj Z, Prifti E, Demiraj A, Strakosha A (2015): Early Clinical Outcome of Acute Poisoning Cases Treated in Intensive Care Unit, Med Arh.; 69(6): 400-404.

Taghaddosinejad F, Sheikhazadi A, Yaghmaei A, Mehrpour O, Schwake L (2012): Epidemiology and Treatment of Severe Poisoning in the Intensive Care Unit: Lessons from a One-Year Prospective Observational Study. J Clinic Toxicol S1:007.

\section{Weibrecht K, Dayno M, Darling C, Bird S} B (2010): Liver Aminotransferases Are Elevated with Rhabdomyolysis in the Absence of Significant Liver Injury, J. Med. Toxicol. 6:294-300. 


\section{Appendix}

Acute Physiology and Chronic Health Evaluation II (Knaus et al., 1985).

\begin{tabular}{|l|l|l|l|l|l|l|l|l|l|}
\hline & $\mathbf{+ 4}$ & $\mathbf{+ 3}$ & $\mathbf{+ 2}$ & $\mathbf{+ 1}$ & $\mathbf{0}$ & $\mathbf{+ 1}$ & $\mathbf{+ 2}$ & $\mathbf{+ 3}$ & $\mathbf{+ 4}$ \\
\hline $\begin{array}{l}\text { Temperature } \\
\text { rectal }\end{array}$ & $\geq 41$ & $39-40.9$ & & $\begin{array}{l}38.5- \\
38.9\end{array}$ & $36-38.4$ & $34-35.9$ & $32-33.9$ & $30-31.9$ & $\leq 29.9$ \\
\hline $\begin{array}{l}\text { Mean arterial } \\
\text { pressure }\end{array}$ & $\geq 160$ & $130-159$ & $110-129$ & & $70-109$ & & $50-69$ & & $\leq 49$ \\
\hline Heart rate & $\geq 180$ & $140-179$ & $110-139$ & & $70-109$ & & $50-69$ & $40-54$ & $\leq 39$ \\
\hline Respiratory rate & $\geq 50$ & $35-49$ & & $25-34$ & $12-24$ & $10-11$ & $6-9$ & & $\leq 5$ \\
\hline $\mathrm{PaO}_{2}$ & & & & & $>70$ & $61-70$ & & $55-60$ & $<55$ \\
\hline Arterial pH & $\geq 7.7$ & $7.6-7.69$ & & $7.5-7.59$ & $\begin{array}{l}7.33- \\
7.49\end{array}$ & & $\begin{array}{l}7.25- \\
7.32\end{array}$ & $\begin{array}{l}7.15- \\
7.24\end{array}$ & $<7.15$ \\
\hline Serum sodium & $\geq 180$ & $160-179$ & $155-159$ & $150-154$ & $130-149$ & & $120-129$ & $111-119$ & $\leq 110$ \\
\hline Serum potassium & $\geq 7$ & $6-6.9$ & & $5.5-5.9$ & $3.5-5.4$ & $3-3.4$ & $2.5-2.9$ & & $<2.5$ \\
\hline Serum creatinine & $\geq 3.5$ & $2-3.4$ & $1.5-1.9$ & & $0.6-1.4$ & & $<0.6$ & & \\
\hline Hematocrit $\%)$ & $\geq 60$ & & $50-59.9$ & $46-49.9$ & $30-45.9$ & & $20-29.9$ & & $<20$ \\
\hline $\begin{array}{l}\text { White blood cell } \\
\begin{array}{l}\text { count } \\
\left(1000 \text { s } / \text { mm }^{3} \text { ) }\right.\end{array}\end{array}$ & $\geq 40$ & & $20-39.9$ & $15-19.9$ & $3-14.9$ & & $1-2.9$ & & $<1$ \\
\hline 15 minus GCS & & & & & & & & \\
\hline
\end{tabular}

Age points (years):
$<44 \quad 0$
$45-54 \quad 2$
$55-64 \quad 3$
$65-74 \quad 5$
$\geq 75 \quad 6$

\section{Chronic health points:}

If a patient has history of severe organ system insufficiency or is immunocompromised

For non-operative or emergency post-operative patients 5 points

For elective post-operative patients 2 points 


\section{الملخص العربى}

\section{متتبئات الوفاة بمرضى التسمم الحاد الأين تم إدخالهم وحدة العناية المركزة بمستثفى جامعة المنوفية}

ملخص البحث:

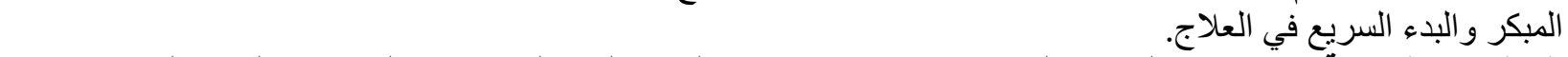
الهذف من الار اسةة: تهذف هذه الإن الدراسة إلى تقييم خصائص مرضى التسمم الحاد الذين تم إدخالهم وحدة العناية المركزة وتقييم

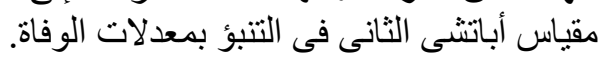
الحالات و طرق البحث: تم إجر اء هذه الدر استة على 152مريضاً الذين تم إدخالهم وحدة العناية المركزة في مستشفى جامعة

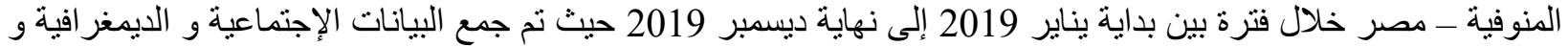

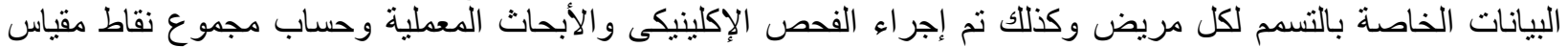

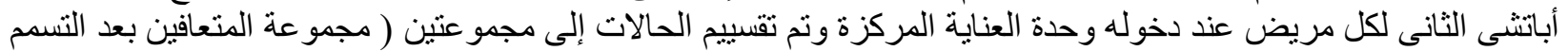

ومجمو عة الوفيات).

النتائج: أظهرت نتائج هذه الدر اسة أن معظم المرضى من الإناث (62.5\% من إجمالى الحالات) ومن المناطق الريفية كما

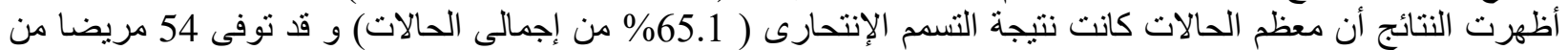
إجمالى الحالات المشاركة فى البحث. وكان أكبر عدد من الحالات قد تسمم بالمو اد الكيميائية الزراعية. الإلة و يمثل التسمم بفوسفيد الزنك نسبة كبيرة من الوفيات.

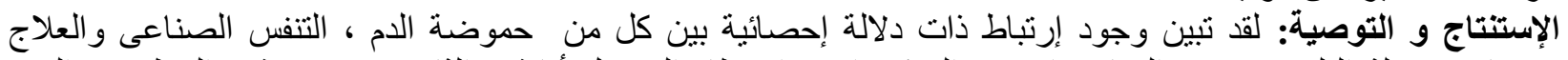

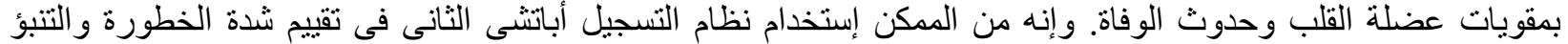

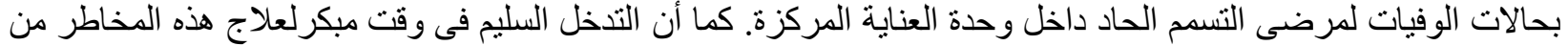
قبل الطبيب المعالج ربما يقلل نسبة الوفيات ويحسن من نتائج هذه الحالات العزئ. 